\title{
A NEW SPECIES OF AND A NEW COMBINATION IN MAGNOLIA (MAGNOLIACEAE)
}

\author{
P. CHALERMGLIN ${ }^{1} \&$ H.P. NOOTEBOOM${ }^{2}$
}

\begin{abstract}
SUMMARY
A new species of Magnolia, M. citrata is described from Thailand, and a new combination made from S China.
\end{abstract}

Key words: Magnolia, Michelia, Thailand.

\section{INTRODUCTION}

The first author, who is engaged in a survey of Magnoliaceae all over Thailand in the project of plant conservation under the initiation of H.R.H. Princess Maha Chakri Sirindhorn, has found several interesting trees including the species described here. He sent complete material to the second author for confirmation. Magnolia citrata belongs to subg. Yulania sect. Michelia subsect. Michelia.

The well-known Michelia yunnanensis from Yunnan still was not validly published as Magnolia, which is done here as Magnolia laevifolia (Y.W. Law \& Y.F. Wu) Noot.

\section{Magnolia citrata Noot. \& Chalermglin, spec. nov. - Fig. 1; Map 1}

\begin{abstract}
Arbor monoecia sempervirens ramunculis glabris, crassis 5-7(-10) mm diametro conspicue lenticellatis, foliis distincte reticulatovenosis coriaceis glabris obovatis 20-25 $\mathrm{cm}$ longis $12-18 \mathrm{~cm}$ latis venis lateralibus $9-11$ petiolo glabro $3-4 \mathrm{~cm}$ longo cicatrice absente. Brachyblastus glabrus $2.5-3.5 \mathrm{~cm}$ longus, $1-1.5 \mathrm{~cm}$ crassus, pedicello absente, bracteis $2-3$ floribis bisexualibus tepalis $9 \mathrm{c}$. albis subsimilibus lanceolatis ad spathulatis $4-4.5 \mathrm{~cm}$ longis, $0.8-1.5 \mathrm{~cm}$ latis, staminibus $1.2-1.6 \mathrm{~cm}$ longis gynoecio excerto $1.6-2$ cm longo carpellis glabris c. 11 fructibus 15-20 cm longis. - Typus: Smitinand 90-269 = Royal Forest Department 96932 (holo BKF), N Thailand, Chiang Mai Province, Mae Taeng District, Mon Anget.
\end{abstract}

Monoecious evergreen tree, 20-35 m high, 100-150 cm diam., bark 3-5 mm thick, lenticelled, with specific strong smell, many branches only at the top. Twigs stout, $5-7(-10) \mathrm{mm}$ diam., seemingly glabrous but the youngest part minutely appressedly yellowish puberulous, conspicuously elliptic lenticellate and with annular scars. Stipules thinly coriaceous, margins yellowish puberulous, free from the petiole. Leaves obovate, $20-25$ by $12-18 \mathrm{~cm}$, coriaceous, rigidulous, deep green above, pale green beneath,

1) Thailand Institute of Scientific and Technological Research, $35 \mathrm{Mu} 3$, Technopolis, Khlong Luang district, Pathum Thani Province 12120, Thailand.

2) Nationaal Herbarium Nederland, Universiteit Leiden branch, P.O. Box 9514, 2300 RA Leiden, The Netherlands. 


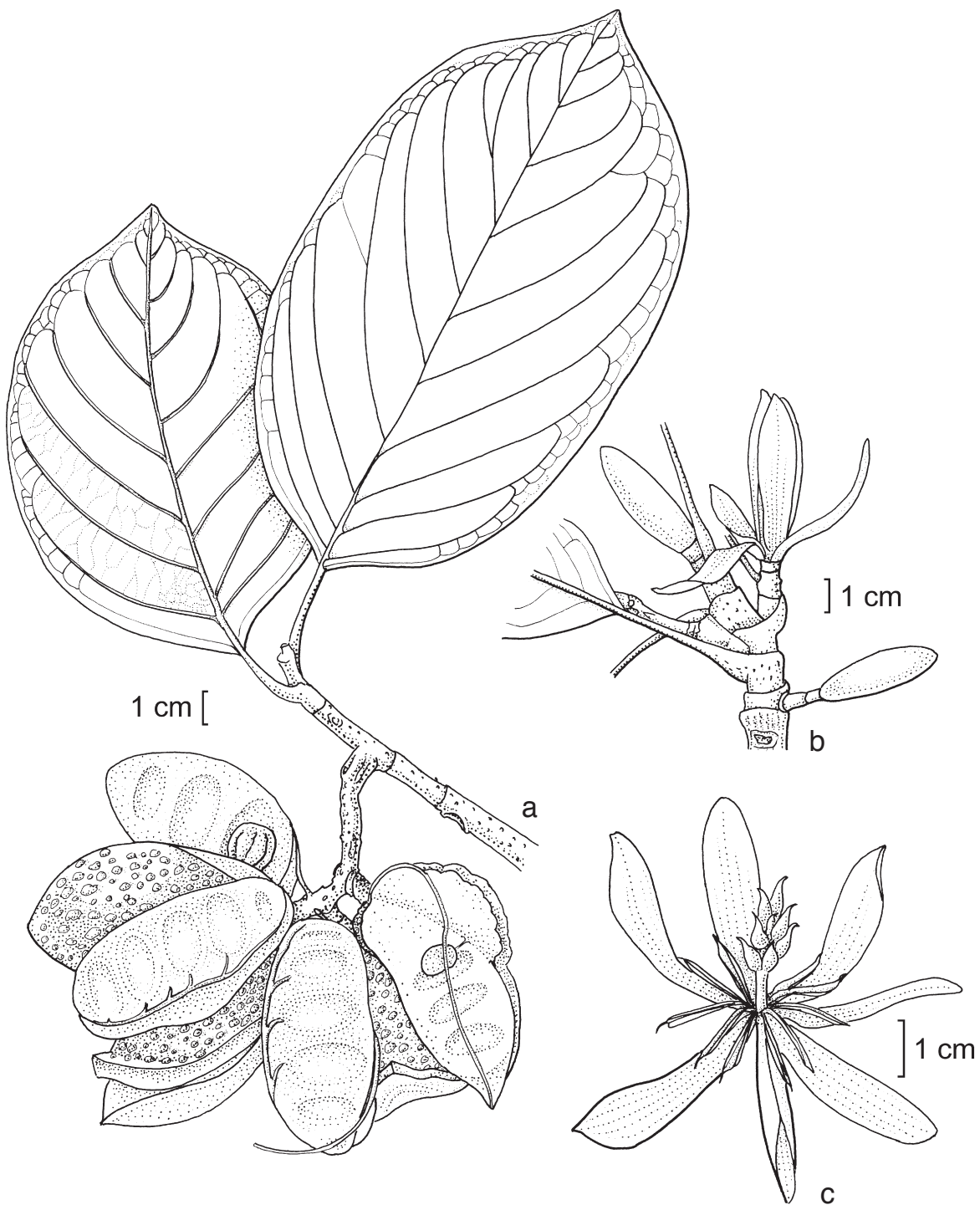

Fig. 1. Magnolia citrata Noot. \& Chalermglin. a. Habit with ripening fruit; b. flower buds; c. flower (a: Smitinand 90-269; b, c: P. Chalermglin 420410).

glabrous on both sides, base rounded but narrowed near the petiole, margin entire, apex rounded, but the very top short-acuminate, midrib impressed above, prominent below, pairs of lateral nerves $9-11$, impressed above, prominent below, meeting in an intramarginal vein $2-4 \mathrm{~mm}$ from the margin, reticulation distinct, densely netted on both sides. Petiole slender, 3-4 mm thick and 3-4 cm long, minutely yellowish appressedly puberulous, without stipular scars. Brachyblast minutely yellowish appressedly puberulous, $2.5-3.5 \mathrm{~cm}$ long and $1-1.5 \mathrm{~cm}$ thick, pedicle absent or minute, 
bracts 2 or 3, chartaceous. Flower bisexual, terminal on the axillary brachyblast, solitary, strongly fragrant, tepals 9 , whitish, subsimilar, thick fleshy, narrowly obovate to spathulate, $4-4.5$ by $0.8-1.5 \mathrm{~cm}$; stamens $0.9-1.2 \mathrm{~cm}$ long, filament $2-3 \mathrm{~mm}$, anthers 6-7 mm, connective appendage subulate, narrowly triangular, 1-1.5 mm; gynoecium 1.6-2 cm long, exserted from stamens; carpels c. 11, seemingly glabrous but minutely tomentulose, ovules c. 10. Fruit 15-20 cm long; ripe carpels 2-8, ovoid to ellipsoid, brown to dark brown, lenticellate, $5-7.5$ by $3.5-5 \mathrm{~cm}$, fruit wall $5-7 \mathrm{~mm}$ thick. Seed obovoid, 18 by $16 \mathrm{~mm}, 4-5 \mathrm{~mm}$ thick.

Distribution - Thailand, northern (Chiang Mai, Nan Province), north-eastern (Loei Province).

Habitat \& Ecology - Hill evergreen forest (tropical rain forest). Altitude 12001400 m. Flowering: April to May; fruit ripening: September to October.

Notes - Local name: Champi Chang.

This species was for a long time misidentified as $M$. lacei, which it resembles. After comparing with the type of Magnolia lacei (W.W. Sm.) Figlar, M. citrata proved to be quite different in characters and size of outer tepals and fruits. The epithet citrata is because the very strong smell from the outer seed coat is the same as Cymbopogon citrata Stapf. The leaves, when crushed, have a liquorice smell.

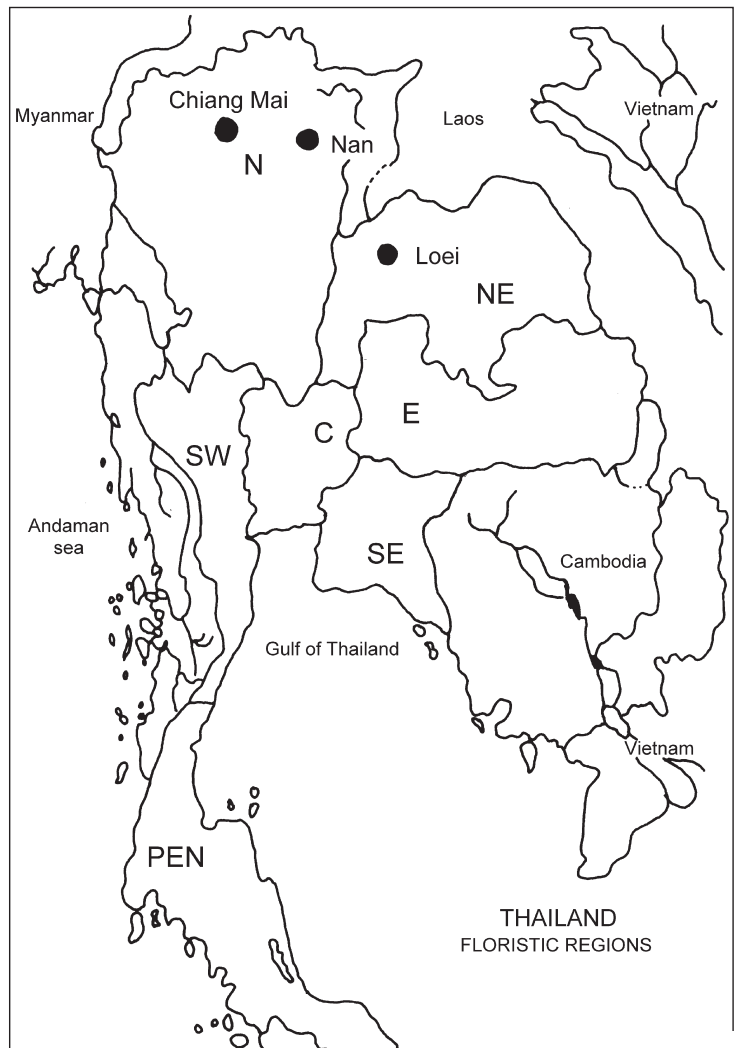

Map 1. Distribution of Magnolia citrata Noot. \& Chalermglin in $\mathrm{N}$ and NE Thailand. 
Many collections were recently made: 1) P. Chalermglin 410618 from N Thailand, Mon Anget, Mae Taeng District, Chiang Mai Province, altitude 1200 m, 18 June 1998 (from the same tree as the type collection); 2) P. Chalermglin 4120409, 420410 from N Thailand, Doi Phuka National Park, Pua District, Nan Province, altitude $1400 \mathrm{~m}$, 10 April 1999; 3) P. Chalermglin 460912, from NE Thailand, Phu Kradung National Park, Phu Kradung District, Loei Province, altitude 1300 m, 12 September 2003.

Note by the second author:

After reducing Michelia to Magnolia all the species were renamed, if necessary, in Magnolia. However, Michelia yunnanensis was incidentally renamed with an invalid and a superfluous name. The valid new combination is made here.

Magnolia laevifolia (Y.W. Law \& Y.F. Wu) Noot., comb. nov.

Magnolia laevifolia (Y.W. Law \& Y.F. Wu) Noot. - Michelia laevifolia Y.W. Law \& Y.F. Wu (1988) 72.

Michelia dandyi Hu (1937) 34, non Magnolia dandyi Gagnep. (1939) 63.

Michelia yunnanensis Franch. ex Finet et Gagnep. (1906) 43, non Magnolia yunnanensis Noot. (1985) 88.

Magnolia dianica Sima \& Figlar (2001) 30.

Note - Magnolia laevifolia (Y.W. Law \& Y.F. Wu) Figlar, comb. nov. (2000) was published without full reference to the basionym, and is therefore invalid and illegitimate. See ICBN art. 33.3. A new combination, or an avowed substitute (replacement name, nomen novum), published on or after 1 January 1953 based on a previously and validly published name is not validly published unless its basionym (name-bringing or epithet-bringing synonym) or the replaced synonym (when a new name is proposed) is clearly indicated and a full and direct reference given to its author and place of valid publication, with page or plate reference and date.

\section{ACKNOWLEDGEMENTS}

The first author gratefully acknowledges the grant received from H.R.H. Princess Maha Chakri Sirindhorn. He thanks Mr. Thinakorn Komkris from Thailand for inviting a group of Magnolia Society members for a Magnolia excursion during which we encountered M. citrata. And he thanks Mr. Dick Figlar for discovering the liquorice smell of the leaves of this species and verifying with his Chinese contacts that M. lacei leaves do not have this smell.

\section{REFERENCES}

Finet, E.A. \& F. Gagnepain. 1906. Espèces nouvelles de l'Asie orientale. Bull. Soc. Bot. France 52, Mém. 4, 1: 43.

Gagnepain, F. 1939. Magnoliacées nouvelles. Notul. Syst. 8: 63-66.

Hu, H.H. 1937. Notulae systematicae ad Floram Sinensium VIII. Bull. Fan Mem. Inst. Biol. Bot. 8: 34.

Law, Y.W. \& Y.F. Wu. 1988. Materials for Chinese Magnoliaceae. Bull. Bot. Res. North-East Forest. Inst. 8: 72.

Nooteboom, H.P. 1985. Notes on Magnoliaceae. Blumea 31: 88.

Sima, Y.K. \& R. B. Figlar. 2001. Some notes on Magnolia subgenus Michelia from China. Yunnan Forest Sci. Technol. 2: 30. 